facilities, and generally, spending on consumables and everyday items that get used up as goods and services are provided. The basis for these spending is government intervention in the economy for sustainable economic growth and development (Musgrave and Musgrave, 2006), as authors have argued that market mechanism alone cannot perform economic functions (Keynesian proponents).

For decades, public expenditures have been expanding in Nigeria, as in any other country of the world. Akpan (2005) opines that the observed growth in public spending appears to apply to most countries regardless of their level of economic development. This necessitates the need to determine whether the behaviour of Nigerian public expenditure and the economy can be hinged on the Wagner's (1883) Law of Ever-increasing State Activity, or the Keynesian (1936) theory and Friedman (1978) or Peacock and Wiseman's (1979) hypotheses.

Abu and Abdullah (2010) observe that government expenditure has continued to rise due to the huge receipts from production and sales of crude oil, and the increased demand for public goods like roads, communication, power, education and health. Besides, there is increasing need to provide both internal and external security for the people and the nation.

Thus, the linkage between public expenditure and economic growth has attracted interest on the part of researchers both in the theoretical and empirical level. This interest is as a result of the role of public expenditure on infrastructure such as roads, ports, communication systems, public research spending, provision of essential services, provision of welfare amenities, maintenance of law and order, communication systems, public research spending, provision of basic educational and health services on the economy, providing good roads and bridges, potential of any country to put smiles on the faces of his people (Nuruden and Usman, 2010).

Kneller and Gemmell (1999) pointed out that composition of government expenditure might exert more influence as compared to the level of government expenditure on economic growth. Maku (2009) stressed that the structure of public expenditure will determine the pattern and form of growth in output of the economy. According to Anyanwu (1997), public expenditure structure addresses the question of how the expenditure is or should be composed. The structure of public expenditure is usually categorized into recurrent and capital expenditure. The recurrent expenditure is composed of administration (general administration, defense, internal security); economic services (agriculture, construction, transport and communications and others); social and community services (education, health, and others); and transfers. In the same vein, capital expenditure includes administration, economic services, social and community services and transfers (Musgrave and Musgrave, 2006; Bhartia, 2004; Anyanwu, 1997; Maku, 2009). Bhartia (2004) opines that these expenditures can be used to provide necessary economic infrastructure for the development of selected economic activities and can be used to give subsidies for increasing their profitability. Public expenditure has an active role to play in reducing regional disparities, developing social overheads, creation of infrastructure of economic growth in the form of transport and communication facilities, education and training, growth of capital goods, industries, basic and key industries, research and development and so on.

Despite these propositions that government expenditure should positively affect the economy, many researchers still report infrastructure decay and lack of human capital. Authorities have blamed it on the fact that costs associated with the running of the government have increased dramatically over the years such that an increasingly reduced proportion of public revenue is available to support and implement the primary functions of government (CBN, 2005). Other factors responsible are the high incidence of corruption and inequity in income distribution occasioned by poor corporate governance in both in the public and private sectors (Sanusi, 2010).

\subsection{Statement of the Problem}

In Nigeria, government expenditure has continued to rise due to the huge receipts from production and sales of crude oil, and the increased demand for public (utilities) goods like roads, communication, power, education and health. Besides, there is increasing need to provide both internal and external security for the people and the nation. Within this context, statistics has it that government expenditure (capital and recurrent) have continued to rise in the last forty (40) years. For instance, total capital and recurrent expenditure increased from N24, $048.6 \mathrm{~m}, \mathrm{~N} 36,219.6 \mathrm{~m}$ in 1990 to $\mathrm{N} 23,9450.9 \mathrm{~m}, \mathrm{~N} 46,1600 \mathrm{~m}$ in 2000 . Between 2001 and 2009 , they had increased from N438, 696.5m, N579, $300 \mathrm{~m}$ to $\mathrm{N} 1,152,796.6 \mathrm{~b}, \mathrm{~N} 2,131,906 \mathrm{~b}$ respectively, and still rise till date. 
Series of administrations have come and gone during this fourth republic. They all claimed to have brought democratic dividends in forms of improved infrastructure, good and quality education, health care services and so on. The extent to which government spending on the various sectors have influenced economic growth of worthy investigation. According to Nurudeem and Usman (2010), the rising government expenditure so far has not translated to meaningful growth and development, as Nigeria ranks among the poorest countries in the world. In addition, many Nigerians have continued to wallow in abject poverty, while more than 50 percent live on less than US\$2 per day. Couple with this, is dilapidated infrastructure (especially roads and power supply) that has led to the collapse of many industries, including high level of unemployment. Moreover, macroeconomic indicators like balance of payments, import obligations, inflation rate, exchange rate, and national savings reveal that Nigeria has not fared well in the last couple of years (CBN, 2008).

Government expenditure over the years, especially during this democratic dispensation, is increasing every year and yet, the successive government claim that their predecessors did not do much to improve the welfare of the citizenry. Therefore, this study investigates the effect of the various components of government expenditure on economic growth. That several studies including Akpan (2010), Cooray (2009), Ejuvbekpokpo (2012), Loto (2011), Nworji, Okwu, Obiwuru and Nworji (2012) and Nurudeen and Usman (2010) have equally studied this issue in Nigeria. However, none of these studies have centered on the democratic dispensation have also prompted this study to cover only the period of the fourth republic (1999 - date). Available empirical literature in Nigeria on government expenditure has been conflicting. Cooray (2009) saw quality of governance as correlate to economic growth; while Ejuvbekpokpo (2012) posited that cost of governance hampers economic development in Nigeria.

\subsection{Objectives of the Study}

The general objective of the study is to investigate the effect of cost of governance on economic growth. The specific objectives include:

1. To examine the effect of federal government general cost of administration on economic growth in Nigeria.

2. To examine the effect of federal government cost of defense on economic growth in Nigeria.
3. To examine the effect of federal government cost of internal security on economic growth in Nigeria.

4. To examine the effect of federal government cost of national assembly on economic growth in Nigeria.

\subsection{Statement of Hypotheses}

$\mathrm{Ho}_{1}$ : Federal government cost of general administrations has no significant effect on economic growth in Nigeria.

$\mathrm{Ho}_{2}$ : Federal government cost of defense has no significant effect on economic growth in Nigeria.

$\mathrm{Ho}_{3}$ : Federal government cost of international security has no significant effect on economic growth in Nigeria.

$\mathrm{Ho}_{4}$ : Federal government cost of national assembly has no significant effect on economic growth in Nigeria.

\section{REVIEW OF RELATED LITERATURE}

\subsection{Conceptual Issues}

\subsubsection{Cost of Governance}

Governance represents more than a means of providing common good, as it can be related to the government capacity to help the citizens' ability to achieve individual satisfaction and material prosperity. Therefore, governance could be compared to the management, supply and delivery of public services to a nation.

The cost of governance is the money spent on administrative processes. It is also known as administrative expenditure. Adewole and Osabuohien (2007) decomposed cost of governance into two: recurrent administrative expenses and capital administrative expenses. They defined cost of governance as costs associated with the running of government. In other words, these are costs incurred by the government is running this affairs. The government helps to sustain the social contract that binds every member of the state.

Similarly, Fluvian (2006) defined cost of governance as any expenditure in maintaining government administrative structures. He also equates cost of governance to total administrative expenditure, which is a part of total federal government expenditure in Nigeria. He said that the justification for using total administrative expenditure as cost of governance stems 
from the fact that administrative expenditures are incurred in governing processes.

According to Drucker (2007), cost of governance is government budget allocated to both capital and recurrent expenditures on maintaining government administrative structures, which appears to be very enormous in Africa the question of efficiency in governance is, therefore, to ensure that public funds are spent judiciously, while public goods and services are sufficiently provided.

According to Fluvian (2006), there are specific factors responsible for the rising cost of governance in Africa. First, there is the issue of inflation. Public project costs are unduly inflated by corrupt politicians. There should be equity. Adewole and Osaabwohien (2007) added that the rising cost of governance in Nigeria is a price we have to pay for undue consideration for equity.

Similarly, the issue of misuse of public funds is another cause of the rising cost of governance in Nigeria (Warimen, 2007). Political leaders inflate the costs of public projects to embellish themselves. Adewole and Osabuohien (2007) also said that the supply of security beyond the optimal level will lead to limited prosperity. In other words, the excess money spent by government on particular set goods affects development, since resources are scarce and should be optimally utilized.

Furthermore, there is population increase. An increase in population implies that there is pressure in the limited available the resources. Fluvian (2006) also said that increase in population implies that more demand for public goods and services, such as education, health services, etc. the need to give every ethnic group adequate representation is another reason for increasing cost of governance.

Another major cause of the persistent rise in cost of governance in Africa vis-a-vis Nigeria is the extra-large civil service sector. This has been described as an institutional factor by Afolugbo (2004). Most public workers in Africa are redundant due to employment of excessive work staff to reduce unemployment. Employees are more than the optimal size, which led to inefficiency and unnecessary increase in cost.

The distribution of Public goods and services in Nigeria is based on the principle of equity. Natural and human resources may skew income distribution in favour of endowed groups when the market is allowed to be the principal mechanism for resource allocation. Free markets are, therefore, more likely to be hindered when pronounced disparities exist in the distribution of natural and human capital endowments among groups that exist in a particular society. This mostly explains why the nationalists of northern extraction did not agree at first with the idea of independence in Nigeria, since their limited investment in human capital would put them at a disadvantage in a post - independent Nigeria (Adewole and Osabudien, 2007).

Nigeria, therefore, put up a political arrangement that ensured that the commanding heights of the economy were left in the domain of the public sector. With the benefit of hind sight, one could say this arrangement signaled the beginning of patronize activities that stifled the market and productivity, promoted rent seeking, brought an imbalance between efforts and rewards, and raised the cost of governance in Nigeria. Cost of governance, according to Afolugbo (2004), is therefore the cost incurred in running the government. It is the cost of performing political duties, and discharging civil services to the public.

In summary, PwC Nigeria (2014) is of the view that the high cost of governance cannot be sustained if the government has plans to improve infrastructure and undertake several capital projects for the benefit of the economy.

\subsubsection{Economic Growth}

For the purpose of this study, we define economic growth according to Ogbulu and Torbira (2012) "as a sustained rise in the output of goods, services and employment opportunities with the sole aim of improving the economic and financial welfare of the citizens". Economic growth is an important issue in economics and is considered as one of the necessary conditions to achieve better outcomes on social welfare, which is the main objective of economic policy. This is consistent with the fact that researchers have been interested in studying economic growth and its determinants for a very long time.

\subsection{Theoretical Framework}

This study is based on the theory of comparative cost Advantage and the theory of government expenditure. While the comparative cost advantage looks at the opportunity cost of expending more resources on running the government (administrative cost), the government expenditure theory looks at the effect of 
government expenditure on public goods on the general welfare of the citizenry.

\subsubsection{Theory of Comparative Advantage}

Given the fact that resources are limited, an increase in the cost of governance implies that there will be decrease in available funds for productive purposes. Thus, adequate resources need to be allotted to vital sectors such as agriculture, industry and education. This arrangement exploits the opportunities offered comparative advantage of costs in governance and costs in production.

Consequently, this study is based on the theory of comparative cost Advantage. To enhance the pace of development, more public funds must be allocated to development projects and there must be reduction in cost of governance. The optimal size of government and the civil service is required for governance to be effective and efficient. According to Olivia (2007), in a nation with government cabinet that is larger than optimal and / or a civil service sector that is extra-large, there will be a rising cost of governance.

The theory of comparative cost Advantage is based on opportunity cost analysis. A rising cost of governance will definitely lead to decreasing cost of production or industrialization and public services such as health, education, security, etc. Olivia (2007), therefore, claimed that the opportunity cost of increasing governance is decreasing finance for productive activities.

To enhance growth and development, governance must be cost-effective and the civil service sector must be efficient; and there must be increasing investment of public funds in productive sectors of the economy. The civil service sector must be reduced to manageable but optimal size. In Nigeria, the civil service sector is extralarge with gross inefficiency and exorbitant cost to the government.

When a state is constituted properly it is possible for the society to end up with an optimal mix of both public and private goods that will maximize social welfare. For economic efficiency, private goods can be more cheaply provided by private firms and public goods by a collective organization - the government.

At equilibrium, according to Adewole and Osabuohien (2007), output can no longer be increased since both the private and the public sectors produce goods in which they have comparative advantage. Thus, the last naira spent on private goods will raise output by as much as the last naira spent on public goods, in Nigeria however, the private sector is more efficient than the public sector, which is characterized by rising costs.

This foregoing analysis is important because the cost of governance is minimal when each (public and private sectors) is only allowed to do what it can do best. Providentially, the free market imposes adequate discipline on the players in a way that drives them to produce at minimal cost. But where well-defined rules are lacking politicians are not constrained to seek to minimize the cost of governance (or administrative expenditure). This is the Nigerian experience. It is hope that the ongoing National Conference will check excesses of the current politicians.

\subsection{Empirical Studies}

Cooray (2009) employed an econometric model that incorporates government expenditure and quality of governance in a cross-sectional study of the relationship between government expenditure and economic growth in 71 countries. The results showed that both the size and quality of governance correlated positively with economic growth.

Ejuvbekpokpo (2012) investigated the impact of cost of governance on economic development in Nigeria using recurrent and capital administrative expenditures as proxy for cost of governance and gross domestic product is used as a proxy for economic growth. Using data from 1970 to 2010 and the Ordinary Least Squares (OLS) technique of analysis, the study reveals that cost of governance hampers economic development in Nigeria. He thus asserted that there is the need to place institutional constraints on public office holders and technocrats in order to minimize the extraction of rent from the state and enhance the availability of public funds for development projects and vital sectors of the economy.

Akpan (2005) used a disaggregated approach to determine the components (that include capital, recurrent, administrative, economic service, social and community service, and transfers) of government expenditure that enhances growth, and those that do not. The author concluded that there was no significant association between most components of government expenditure and economic growth in Nigeria. 
Nurudeen and Usman (2010) observes that rising government expenditure has not translated to meaningful development as Nigeria still ranks among world's poorest countries. They then investigated the effect of government expenditure on economic growth using a disaggregated analysis. The results reveal that government total capital expenditure, total recurrent expenditures, and government expenditure on education have negative effect on economic growth. On the contrary, rising government expenditure on transport and communication, and health results to an increase in economic growth. The proposed increased capital expenditure and recurrent expenditure, including expenditures on education, investment in the development of transport and communication, as well as ensuring that funds meant for the development of these sectors are properly managed.

Loto (2011) investigated the growth effect of government expenditure on economic growth in Nigeria over the period of 1980 to 2008, with a particular focus on sectoral expenditures. The variables were tested for stationarity and cointegration analysis was also carried out using the Johansen co-integration technique. Error correction test was also performed. The essence of the use of the techniques is to identify the interactions between government spending on these sectors (education, health national security, transportation and communication and agriculture) and economic growth in Nigeria. The result shows that in the short-run, expenditure on agriculture was found to be negatively related to economic growth. The impact of education, though also negative was not significant. The impact of expenditure on health was found to be positively related to economic growth. Though expenditures on national security, transportation and communication were positively related to economic growth, the impacts were not statistically significant. It is possible that in the long-run, expenditure on education could be positive if brain drain could be checked.

Nworji, Okwu, Obiwuru and Nworji (2012) examined the effect of public expenditure on economic in Nigeria for the period $1970-2009$. The tool of analysis was the OLS multiple regression models specified on perceived causal relationship between government expenditure and economic growth. The major objective of the study was to analyze the effect of public government spending on economic in Nigeria based on time series data on variables considered relevant indicators of economic growth and government expenditure. Therefore, time series data included in the model were those on gross domestic product (GDP), and various components of government expenditure. Results of the analysis showed that capital and recurrent expenditure on economic services had insignificant negative effect on economic growth during the study period. Also, capital expenditure on transfers had insignificant positive effect on growth. But capital and recurrent expenditures on social and community services and recurrent expenditure on transfers had significant positive effect on economic growth.

\section{METHODOLOGY}

\subsection{Research Design}

The study is an ex-post facto research design. An expost facto design requires the use of variables which the researcher does not have the capacity to change its state or direction in the course of the exercise (Onwumere, 2009). The ex-post-facto design was used because the variables used in this study are already documented by highly research based institutions like the World Bank, IMF, CBN, among others. Thus, researchers have to adapt to and rely on such official publications for valid and reliable academic exercise.

\subsection{Data and Sources}

The study used quantitative data generated from secondary sources. The data for the study generated from CBN Statistical Bulletin, 2014. The period covered is the fourth republic of the Nigerian democratic era which extends from 1999 till date, but availability of data the analysis runs from 1999 to 2014 . The data is shown on Appendix 1. The variables of the study are the federal government disaggregated expenditures based on the functional classifications of administration, social and community services, economic services, and transfers.

\subsection{Model Specification}

This study aimed to further investigate into the effect of cost of governance on economic development of Nigeria as studied by Ejuvbekpokpo (2012). Ejuvbekpokpo (2012) decomposed cost of governance as total administrative expenditure, into recurrent administrative expenditure and capital administrative expenditure. This study uses a modified form of cost of governance model based on CBN statistical bulletin functional disaggregation of administrative expenditure. 
The functional of the model is:

$\mathrm{GDP}=\mathrm{f}($ cost of governance $)$

Where

- Cost of governance includes all administrative expenses of the government. In Nigeria, federal government administrative expenditure based on the CBN statistical bulletin (2012) includes general administration (GA), defence (DEF), internal security (ISEC) and national assembly (NAS).

- GDP is the proxy for economic growth measures with Gross Domestics Product at current factor cost.

The equation of the expected relationship is thus: $\mathrm{GDP}=\mathrm{a}_{\mathrm{o}}+\mathrm{a}_{1} \mathrm{GA}+\mathrm{a}_{2} \mathrm{DEF}+\mathrm{a}_{3} \mathrm{ISEC}+\mathrm{a}_{4} \mathrm{NAS}+\mu$

$a_{0}=$ intercept; $a_{1}, a_{2}, a_{3}$ and $a_{4}$ are the coefficients of each variable of the regression whereas $\mu$ represents the error term.

\subsection{Analytical Techniques}

A multiple regression model has been developed for this study which is more reliable in terms of the estimates of the parameters than a single regression model. The data are analysed using E-View software package The Ordinary least squares (OLS) of simple regression model will generate statistics that explains the nature of the effect of government expenditure on growth. These include the coefficient of determination $\left(\mathrm{R}^{2}\right)$, f-test, t-test and Durbin-Watson statistic. The decision rule is the reject the null hypotheses when the calculated p.value is below 5\% level of significance, otherwise accept. The statistics for analysis are explained below:

1. Adjusted Coefficient of Determination (Adj $\mathrm{R}^{2}$ ) Test $=$ measures the explanatory power of the independent variables on the variables in the dependent variable. The $r^{2}$ normally makes an overestimation of the true value of the population especially when small sample is used. The Adj $\mathrm{r}^{2}$ correct this problem (Pallant, 2004). Therefore, we use Adj $r^{2}$.

2. Student T-Test $=$ measures the individual significance of the estimated independent variables.

3. F-Test $=$ measures the overall significance.

4. The coefficient is used to measure the extent of the effect of the individual variables to variation in the dependent variable.

5. Durbin Watson (DW) Statistics: This test for autocorrelation in the regression.

\section{PRESENTATION AND INTERPRETATION OF RESULTS}

\subsection{Statistical Properties of the Variables}

Table 4.1: Summary Statistics of the Employed Variables

\begin{tabular}{|l|l|l|l|l|l|}
\hline & \multicolumn{1}{|c|}{ GDP } & \multicolumn{1}{c|}{ GA } & DEF & ISEC & NAS \\
\hline Mean & 31798.40 & 311.9713 & 128.3244 & 163.7519 & 60.47813 \\
\hline Std. Dev. & 29269.98 & 213.1988 & 99.50874 & 111.9798 & 46.94765 \\
\hline & & & & & \\
\hline Jarque-Bera & 2.452209 & 1.297602 & 2.744176 & 1.347213 & 1.511101 \\
\hline Probability & 0.293433 & 0.522672 & 0.253577 & 0.509866 & 0.469752 \\
\hline & & & & & 16 \\
\hline Observations & 16 & 16 & 16 & 16 & 16 \\
\hline
\end{tabular}

Source: Authors computation from Eviews 8 results

The summary statistics of the employed variables for are presented in Table 4.1. The summary statistics provided information about the means, standard deviations (SD of all the employed variables. Mean is the average value of the series and is a robust measure of the centre of the distribution that is less sensitive to outliers. Standard deviation measures dispersion in the series. The employed variables presented in Table 4.1 included Gross Domestic Product (GDP), Cost of General Administration (GA), Cost of Defence, Cost of Internal Security and Cost of National Assembly.

The result shows that the mean of the variables are larger than their standard deviations. This indicates that the figures in each variable are not far away from each 
other. This implies that variables could not normally distributed.

A confirmatory distributional test is done with the help of the Jarque-Bera statistics. The null hypothesis is that "there is normal distribution". From the result of the Jarque-Bera for each variable, the probability values are greater than 0.05 level of significance. Thus we do not reject the null hypothesis. Thus we conclude the variables are normally distributed. This confirms that we can use parametric tool for our analyses.

\subsection{Correlation Analysis}

The correlation analysis is carried out to help us to appreciate the degree of association that exist between the dependent and the independent variables as well as among the explanatory variables, correlation analysis was carried out. This is used to test for multicolinearity among the explanatory variables. Table 4.2 presented the correlation analysis of the employed variables.

Table 4.2: Correlation Analysis of the Employed Variables

\begin{tabular}{|c|c|c|c|c|c|}
\hline & GDP & GA & DEF & ISEC & NAS \\
\hline GDP & 1 & & & & \\
\hline GA & 0.7334 & 1 & & & \\
\hline DEF & 0.9681 & 0.6319 & 1 & & \\
\hline ISEC & 0.9274 & 0.5993 & 0.4873 & 1 & \\
\hline NAS & 0.9600 & 0.5181 & 0.5846 & 0.36736 & 1 \\
\hline
\end{tabular}

Source: Authors computation from Eviews 8 results

A correlation coefficient of 0.7 and above is said to be strong association, correlation between 05 and 6 is said to be moderate while any correlation 0.1 to 0.4 can be said to be weak. The result indicate that the correlation coefficient for GDP and the explanatory variables are above 0.7 which means that there is strong positive correlation between GDP and the variables of cost of administration (GA, DEF, ISC and NAS) in Nigeria. This implies that the higher the level of economic growth in Nigeria, cost of running the government tend to increase.
However, the correlations for each of the explanatory variables are below 0.7 which indicate moderate or weak correlations. Since the variables are not strongly correlated, we do not suspect multicolinearity in the model. This suggests that the variables included in the model will be distort the result by influencing the contributing of one another in the model. Thus, the Ordinary Least Square regression can be used to regress the model.

\section{Table 4.3: OLS Regression of the Effect of Cost of Governance on Economic Growth}

\begin{tabular}{|c|c|c|c|c|}
\hline \multicolumn{5}{|c|}{ Dependent Variable: GDP } \\
\hline Variable & Coefficient & Std. Error & t-Statistic & Prob. \\
\hline GA & 8.665839 & 5.990348 & 1.446633 & 0.1759 \\
\hline DEF & 169.9956 & 16.00188 & $10.62347^{* * *}$ & 0.0000 \\
\hline ISEC & -106.1693 & 31.03174 & $-3.421313^{* * *}$ & 0.0057 \\
\hline NAS & 496.5033 & 65.97839 & $7.525241^{* * *}$ & 0.0000 \\
\hline C & 5361.831 & 1304.840 & $4.109186^{* * *}$ & 0.0017 \\
\hline R-squared & 0.993639 & & \\
\hline Adjusted R-squared & 0.991325 & & \\
\hline F-statistic & 429.5508 & Durbin-Watson stat & 2.180348 \\
\hline Prob(F-statistic) & 0.000000 & & & \\
\hline
\end{tabular}

Note: $* *$ denotes significant at $1 \%, * *$ denotes significant at $5 \%$; denote significant at $10 \%$.

Source: Authors computation from Eviews 8 results 
The result of the Adjusted Coefficient of Determination (Adj $\mathrm{R}^{2}$ ) is 0.99 indicating that about $99 \%$ of Nigerian

economic growth can be explained by the cost of running the government. This implies that administration can heavily affect the growth of the economy. The F-statistics is 429.55 with probability value $<0.05$. Thus we conclude that all the variables of cost of governance (cost of administration) have significant effect on economic growth in Nigeria.

The Durbin Watson statistics is 2.180 which is within the bound of 2. This indicate that there is no autocorrelation in the model. This confirms that the Ordinary Least Square regression can be used to regress the model.

Further analyses now centres on the contribution of each of the explanatory variables to GDP. The equation of the result is thus shown below:

$\mathrm{GDP}=5361.83+8.67 \mathrm{GA}+169.99 \mathrm{DEF}^{* * *}-$

106.17ISEC*** + 496.50NAS***

The equation shows that GA (8.67), DEF (169.99) and NAS (496.50) have positive effect while ISEC (106.17) has negative effect on GDP. This indicate that a unit increase in the general administration will lead to 8.67 units of increase GDP; a unit increase in defence will lead to 169.99 units of growth in GDP; and a unit increase in national assembly will lead to 496.50 increase in GDP. However, a unit increase in cost of internal security will lead to 106.17 unit decrease in GDP. This suggests that the cost of general administration, defence and national assembly could enhance growth while the cost of internal security could negatively affect growth in Nigeria. This implies that money spent in general administration, defence and national assembly are more effectively utilised while money spent on internal security are not well appropriated.

To test for the hypotheses, the t-statistics is used. The probability values of DEF and NAS are below 0.05 level of significance, thus we reject their null hypotheses. This indicates that cost of defence and cost of national assembly have significant positive effect on economic growth of Nigeria. However, the p.values for Cost of Internal Security and Cost of General Administration are above the 0.05 level of significance, and thus these variables do not have significant effect on growth in Nigeria.

\section{CONCLUSION AND RECOMMENDATIONS}

\subsection{Summary of Findings}

Thus the study summaries result thus:

1. Federal government cost of general administrations has no significant effect on economic growth in Nigeria.

2. Federal government cost of defense has significant effect on economic growth in Nigeria.

3. Federal government cost of internal security has significant effect on economic growth in Nigeria.

4. Federal government cost of national assembly has significant effect on economic growth in Nigeria.

\subsection{Conclusion}

The study has investigated the effect of cost of governance on economic growth of Nigeria. The results has shown that general administration, defence and cost of national assembly are capable of enhancing economic growth but only defence and national assembly has significant positive effect on growth. However, cost of maintaining internal security has adverse significant effect on growth of Nigeria. This might suggest that bogus Security Votes to the Governors, and frivolous spending on the police and paramilitaries are killing the economy. Equally, the general administration does have significant effect suggest that Nigerian civil servants are unproductive.

\subsection{Recommendations}

Based on the findings and conclusion drawn, it is recommended as follows:

1. The money spend on internal security should to investigated and cost-benefit analyses should be carried out on the parastatals that receive the proceeds of internal security. This exercise will enable the government find out the spending unit that accounts for the unproductive tendency in the system.

2. The civil service should restructure to bring in professionalism into the system. Employment should be based on need for productivity. Training should be organised for the present civil servants to reorient their attitude to work. 
International Journal of Trend in Scientific Research and Development (IJTSRD) ISSN: 2456-6470

\section{REFERENCES}

1. Abu, N. \& Abdullahi, U. (2010). Government Expenditure and Economic Growth in Nigeria, 1970-2008: A Disaggregated Analysis. Business and Economics Journal, Vol.4

2. Adewole, A.N. \& Osabuohien, E.S.C. (2007). Analysis of the Cost of Governance and Options for its Reduction in Nigeria. Nigerian Journal of Economic and Social Studies, 49(1), 137 - 159.

3. Afolugbo, O. (2004). "Institutions as the fundamental cause of Rising cost of Governance" American Economic Review, 5:1369 - 1401, December, 2004.

4. Afonso, A. \& Furceri, D. (2007). Government Size, Composition, Volatility and Economic Growth. Department of Economics, School of Economics and Management, Technical University of Lisbon. Working paper WP04/2008/DE/UECE.

5. Akpan, N. I. (2005). Government Expenditure and Economic Growth in Nigeria: A Disaggregated Approach. CBN Economic and Financial Review, 43(1), $87-98$.

6. Anyanwu, J. C. (1997). Nigerian Public Finance, Onitsha: Joanee Educational Publishers.

7. CBN Statistical Bulletin (2008), Golden Jubilee Edition, December, Abuja, Nigeria

8. Dickey, D. \& Fuller, W. (1979). Distribution of the Estimators for Autoregressive Time Series with a Unit Root, Journal of American Statistical Association, 74: 427-431.

9. Drucker, P. (2007). Governance. Harvard Business Review, 45(2), 82-98.

10. Ejuvbekpokpo, S. (2012). Cost of Governance on Economic Development in Nigeria. Global Journal of Management and Business Research, 12(13) Version 1.0, pp. 18 - 24. Retrieved from https://globaljournals.org/GJMBR_Volume12/3Cost-of-Governance-on-Economic.pdf.

11. Fluvian, G. (2006). The Rising Cost of Governance in Africa. Journal of Public Administration, 22(9), $441-463$.

12. Johansen, S. (1991). Estimation and Hypothesis Testing of Co-integration Vectors of Gaussian Vector Autoregressive Models, Econometrica, 59(6): 1551-1580.
13. Kneller, R., Bleaney, M. \& Gemmell, N. (1999). Fiscal Policy and Growth: Evidence from OECD Countries. Journal of Public Economics, 74, 171190.

14. Keynes, J.M. (1936) General Theory of Employment, Interest and Money, London: Macmillan.

15. Loto, M. A. (2011). Impact of Government Sectoral Expenditure on Economic Growth, Journal of Economics and International Finance, 3(11), 646652,. Retrieved from http://www.academicjournals.org/JEIF.

16. Maku, O. E. (2009). Does Government Spending Spur Economic Growth in Nigeria? Munich Personal RePEc Archive. Retrieved from http://mpra.ub.uni-muenchen.de/17941/MPRA

Paperno. 17941.

17. Musgrave, R. A. \& Musgrave, P. B. (2006). Public Finance in Theory and Practice (5th ed.) New Delhi: Tata McGraw Hill Publishing company.

18. Nurudeen, A. \& Usman, A. (2010). Government Expenditure and Economic Growth in Nigeria, 1970-2008: A Disaggregated Analysis. Business and Economics Journal, 4, 1 - 11. Retrieved from http://www.arabianjbmr.com/pdfs/OM_VOL_1_\%2 $811 \% 29 / 4 . p d f$.

19. Nworji, I. D., Okwu, A.T, Obiwuru, T. C. \& Nworji, L.O., (2012). Effects of Public Expenditure on Economic Growth in Nigeria: A Disaggregated Time Series Analysis, International Journal of Management Sciences and Business Research, 1(7). 1 - $15 . \quad$ Retrieved from http://www.ijmsbr.com/Volume $\% 201$,Issue $\% 207 \%$ $20 \% 286 \% 29 \% 20$ Andy.pdf.

20. Ogbulu, O. M. \& Torbira, L. L. (2012). Budgetary Operations and Economic Growth: The Nigerian Perspective. British Journal of Arts and Social Sciences, 4(2), 180 - 194. Retrieved from http://www.bjournal.co.uk/BJASS.aspx.

21. Olivia, R. (2007). Comparative cost Advantage Analysis of Rising cost of Governance. The American College, pp 690 - 750 .

22. Okoro, A. S. (2013). Government Spending and Economic Growth in Nigeria (1980-2011). Singaporean Journal of Business Economics, and Management Studies, 2(5), 81 - 92. Retrieved from http://www.singaporeanjbem.com $\% 2$ Fpdfs $\% 2 F S G$ VOL_2_\%285\%29\%2F10.pdf. 
23. Onwumere, J. U. J. (2009). Business and Economic Research Method, Enugu: Vougasen publishers.

24. Pallant, J. (2004). SPSS Survival Manual. United Kingdom: Open University Press.

25. Peacock, A. \& Wiseman, J. (1979). Approaches to the Analysis of Government Expenditures Growth. Public Finance Quarterly, Jan. 3-23.

26. PwC Nigeria (2014). Nigeria's 2014 budget, Tax and economic analyses. Retrieved from http://www.pwcnigeria.typepad.com\%2Ffiles\%2Fni gerias-2014-budget---tax-and-economicanalyses.pdf .

27. Sanusi, L. S. (2010). Growth Prospects For The Nigerian Economy. Convocation Lecture delivered at the Igbinedion University Eighth Convocation Ceremony, Okada, Edo State, November 26, 2010. Prepared by the Research Department of the Central Bank of Nigeria.

28. Wagner, A., (1883). Three Extracts on Public Finance. Translated and reprinted in R.A. Musgrave and A.T. Peacock (eds), Classics in the Theory of Public Finance, London: Macmillan, 1958. 